\title{
A study of biological markers in HIV disease progression and management in the highly active antiretroviral therapy (HAART) era
}

\author{
Kandi Venkataramana \\ Submitted in total fulfilment of the requirements of the degree of doctor of philosophy \\ Dr NTR University of Health Sciences, Vijayawada \\ Department of Microbiology, Apollo Health City, Jubilee Hills, Hyderabad \\ Email address: \\ ramana_20021@gmail.com (K. Venkataramana) \\ To cite this article: \\ Kandi Venkataramana. A Study of Biological Markers in HIV Disease Progression and Management in yhe Highly Active Antiretroviral \\ Therapy (HAART) Era, American Journal of Bioscience and Bioengineering. Vol. 1, No. 2, 2013, pp. 24-37. \\ doi: $10.11648 /$ j.bio.20130102.11
}

\begin{abstract}
Human Immunodeficiency Virus (HIV), the causative agent in AIDS has been a challenge to medical fraternity from the time since it was first discovered in 1983. About 40 million people are living with HIV infection globally and $99 \%$ of the infected people are in south East Asia (SEA). With inception of highly active antiretroviral therapy (HAART), the quality of life of HIV infected individuals is gradually improving. The number of people contracting new infections has been on decline globally and those having access to HAART are increasing. Close monitoring of HIV infected patients is essential in reducing the morbidity and mortality of HIV patients. Monitoring HIV disease progression, deciding the time to initiate HAART requires evaluation of TCD4+ cell counts and HIV/RNA viral load at regular intervals. Considering the fact that it is the resource restrained developing countries that carry most of the burden of HIV, studies recently have been carried out to evaluate the utility of low cost, easily performed alternate biomarkers that can be used for HIV disease management and response to HAART therapy. Very few studies are available that have demonstrated the role of alternate biomarkers to monitor HIV disease progression and assessing response to HAART.
\end{abstract}

Keywords: Human Immunodeficiency Virus (HIV), Highly Active Antiretroviral Therapy (HAART), Alternate biomarkers

\section{Introduction}

Human immunodeficiency virus (HIV) is the causative agent in AIDS. Since 1981, when the first AIDS cases were reported, more than 33 million people have been diagnosed as infected with HIV (UNAIDS, 2006). A large part of the infected individuals live in relatively poor and developing countries. Due to the large scale of morbidity and mortality it causes, HIV is fast becoming a major threat in developing/third world countries including the Indian sub-continent. Infection with HIV is associated with prolonged latent period during which the virus continues to actively replicate, usually resulting in symptomatic illness (Miedema et al., 2006). The HIV disease progression, which is highly variable in infected individuals, is characterized as rapid, typical or intermediate and late or non- progressors. The majority of infected individuals(70-80\%) experience intermediate disease progression in which they show HIV RNA rise, CD4+ T- cell decline and later development of AIDS related illness in $6-10$ years. $10-15 \%$ of the infected patients whose CD4+ T- cells rapidly decline and go into AIDS within few years of infection are called rapid progressors. The late progressors $(5 \%)$ can remain asymptomatic and healthy without showing significant changes in CD4+ Tcell counts even for 10 years.

The biological basis of this variability in the disease progression is still unknown but few studies have attributed it to be due to defective virus (Kirchhoff F et al., 1995). Many clinical and laboratory markers have been used to estimate disease progression in HIV1 infection. Markers of AIDS development include viral markers(plasma HIV RNA load, serum p24 Ag, serum anti p24 antibodies), Surrogate markers(antibodies against p17,gp 120, gp 41 and nef gene product) and nonspecific markers including CD4+ Tcell counts, 
CD8+ Tcell counts and Delayed type hypersensitivity test (DTH) (Kannangai et al ., 2008). Other Alternate markers include elevated serum $\beta 2$ microglobulin, neopterin (Derythro-1',2',3'-trihydroprpylptrin), DHEAS (dehydroepiandrosterone), serum cortisol, and many others including CRP,ESR, serum albumin, Tumor Necrosis Factor(TNF), Interferon- $\gamma$, Interleukin-2(IL-2), IL-4 (Sevigny et al ., 2007). Even with many advances in the availability and effectiveness of HAART (Highly active antiretroviral therapy), still it is difficult to eradicate the infection. More so the patients receiving HAART will experience significant side effects. Recent studies also have documented a number of metabolic abnormalities including dyslipidemia which can be used as prognostic markers and may predict cardiovascular risk in HIV seropositive individuals ( $\mathrm{Oh} \mathrm{J}$ et al., 2007). Therefore it is suggested that before initiating HAART the patients' hematological and other biochemical parameters are to be evaluated and regularly monitored during the therapy. Studies conducted in the past have also demonstrated the role of HIV infection by itself irrespective of HAART therapy can result in the development of metabolic disorders including altered lipid metabolism (Rasheed S., 2008). Previous reports have also suggested the association of cardiovascular disease (CAD) and HAART therapy (Kramer AS., 2009). The knowledge of HIV infection has expanded tremendously that led to significant improvement in the treatment, leading to decrease in morbidity and mortality. Unfortunately the progress achieved in the development of treatment and vaccine has been restricted or confined to western world. Research is now concentrated on finding alternate and cost effective biological markers which can help physicians in deciding the start of antiretroviral therapy and predicting HIV disease progression. Our study impresses on the need for evaluating certain biological markers which can be easily performed and low cost markers that can be useful in monitoring HIV disease progression and HIV disease management in HAART era. Increased studies on the utility of alternate biological markers in HIV could pave the way for better understanding of immuno pathogenesis of HIV disease and improve laboratory testing strategies that can be used in predicting clinical stage, initiation of HAART and management of HIV disease.

\section{Aim}

The aims of the present study include

Evaluation of certain biological markers in HIV seropositive individuals who are HAART naive and comparing them with HIV negative normal healthy individuals.

Evaluation of certain biological markers in HIV seropositive individuals who are HAART naive and following those on HAART therapy for at least 3-6 months and assessing their role in HIV disease progression and disease management. Assessing utility of biological markers in predicting CD4 counts and their usefulness in monitoring HIV disease progression and disease management in

\section{HAART era}

\section{Review of Literature}

In the event of global HIV prevalence the bulk of HIV infected individuals is carried by the sub Saharan Africa and the Indian subcontinent. The availability and affordability of HAART has dramatically reduced the mortality of HIV infected people and increased the life expectancy. The poor financial position of some third world countries makes it difficult to manage the HIV infected patients which requires costly Infrastructure to assess regularly the TCD4+ cell counts and HIV/RNA viral load. In such cases the patient management can be done and disease progression assessed by other surrogate or alternate markers. The Tlymphocyte cell surface glycoprotein cluster determinant 4 (CD4) has been studied extensively because it is the major receptor for HIV. Repeated or persistent exposure of the immune system to viral antigen leads to general impairment of functional capability of immune competent cells, immune system dysfunction and an abnormal programmed cell death. Consequently, there is progressive reduction in the number of CD4+ lymphocytes in HIV-infected individuals. Although the CD4+ lymphocyte count provides important prognostic information, determination of lymphocyte subsets requires resources and technical expertise not routinely available in most developing countries. This is particularly true in most sub-Saharan African countries where approximately $67 \%$ of the world's HIV-infected population resides. In these countries, affordable alternative markers of immune-suppression in HIV-infected patients would be valuable. Such markers would improve the ability of health care workers to monitor disease progression. The serum albumin level is considered one of these alternatives, as it has been shown that a low level of serum albumin, i.e., $3.5 \mathrm{mg} / \mathrm{ml}$, after sero-conversion is associated with faster HIV disease progression. There are reports on the association of high levels of plasma highly sensitive C-reactive protein (CRP) and HIV disease progression. The costs for the estimation of CD4+ T-cell counts, HIV-1 loads, and serum/plasma albumin levels are $\$ 15, \$ 100$, and $\$ 2$, respectively. Hence, in developing countries, where patient resources are poor, the interval between CD4+ T-cell estimation and HIV-1 load testing may be increased by introducing more frequent testing of the serum albumin level, which will prove economical, while the patients are on ART.

In developing countries, the usability of peripheral blood constituents that are low-cost alternatives to CD4-positive (CD4+) T-cell and human immunodeficiency virus type 1 (HIV-1) RNA estimation should be evaluated as prognostic markers. The differences in the albumin levels before and after ART or ATT were significant $(P<0.05)$, while the differences in DHEAS and CRP levels were not significant $(P>0.05)$. When levels of DHEAS among the individuals who were followed up were analyzed, $13(44.8 \%)$ in the ART group and $9(69 \%)$ in the ATT group showed an increase following treatment. Prior to treatment of HIV- 
infected individuals, there was a significant positive correlation of CD4+ T-cell counts and a negative correlation of viral load with albumin and DHEAS levels $(P<0.01)$. Among the three plasma markers tested, plasma albumin and, to some extent, DHEAS show promise as prognostic markers in monitoring HIV infection (Kannangai, R et al., 2008). The WHO advocates the use of total lymphocyte count as an alternative to CD4+ lymphocyte count when the latter is not available. Other simple blood indices, such as low red blood cell count, low haematocrit or hemoglobin, and elevated erythrocyte sedimentation rate (ESR) have been identified to be predictors of decreasing CD4+ lymphocyte counts. Other studies have evaluated the role of potential cofactors for progression to AIDS or AIDS-related complex among HIV-infected persons. The majority of these studies was conducted in developed countries and may not be applicable to developing countries. Hence, there is a critical need for data from less developed countries, such as Tanzania,

The receiver operating characteristic (ROC) curve was used to determine the cut-off point which maximizes both sensitivity and specificity, and the area under the ROC curve was used to calculate the accuracy of the models. It was observed that most HIV seropositive women were asymptomatic in the WHO clinical stage 1 . The distribution of T-lymphocyte subsets observed in this population was comparable to those reported in other studies involving asymptomatic HIV-seropositive pregnant women. CD4+ lymphocyte count of $<200$ cells $/ \mathrm{mm}^{3}$ is considered by the Centre for Disease Control and Prevention (CDC) as an AIDS-defining laboratory criterion. Although a substantial proportion of HIV seropositive women $(12.8 \%)$ met this laboratory criterion, most of these women were healthy and had no symptoms suggestive of AIDS. This suggests that laboratory parameters alone may not be adequate to define clinical stages of HIV disease among pregnant women. (S $\mathrm{H}$ Kapiga et al., 2000). Studies in human immunodeficiency virus (HIV) infected adults have demonstrated association of total lymphocyte count (TLC) $<1200 / \mathrm{mm}^{3}$ and subsequent disease progression or mortality. The association of other surrogate makers such as hemoglobin (HB), and erythrocyte sedimentation rate (ESR) with CD4 count and disease progression has also been suggested. A study from India included 215 antiretroviral treatment naive HIV-I infected adults measuring their CD4 positive T cell counts, TLC, HB and ESR of study. Spearman's rank order correlation and Receiver Operating Characteristic were used for sensitivity, specificity, positive and negative likelihood ratios for cut-off T value of TLC $<\mathrm{I} 200 / \mathrm{mm}^{3}$ for predicting CD4 counts $<200$ cells/ $\mathrm{mm}^{3}$ and $<350$ cells $/ \mathrm{mm}^{3}$ were. The association of $\mathrm{HB}<10,11,12 \mathrm{~g} / \mathrm{dl}$ and $<10,12,14 \mathrm{~g} / \mathrm{dl}$ for CD4 counts $<200$ cells $/ \mathrm{mm}^{3}$ and $<350$ cells/ $\mathrm{mm}^{3}$, respectively), and ESR «10, 20 and $30 \mathrm{~mm}$ fall after 1 hour) with these two CD4 counts cut-off values were suboptimal. This study reveals the poor association of TLC, HB, and ESR with CD4 counts in HIV infected adults, thus highlighting the need to review the utility of these surrogate markers, for predicting CD4 counts in people living with HIV/AIDS. While this study demonstrates that in HIV-I infected individuals the association of TLC, HB and ESR in predicting of CD4lymphocyte counts is poor, the same needs to be validated with large scale, multi-centric studies in India so as to investigate the utility of such cheaper laboratory test modalities, namely TLC, HB, and ESR, if any, in predicting HIV-l disease progression and initiating antiretroviral therapy in resource limited settings (Saurav Sen et al., 2011). Anemia is frequently experienced by HIVpositive individuals and has been shown to be a strong independent predictor of disease progression and death. Highly active antiretroviral therapy (HAART) is associated with an improvement in anemia, but little work has been carried out on the short- and longer-term prognostic value of hemoglobin for progression to AIDS and death amongst those receiving HAART. Serum albumin has also been proposed as an alternative prognostic marker, as hypoalbuminaemia is associated with mortality in many other acute and chronic conditions. Another study reported that low serum albumin concentrations were associated with increased mortality over 3 years. These findings were confirmed by Sabin and colleagues, who showed that low serum albumin was independently associated with an increased risk of AIDS and death over a longer time period (15-20 years) in individuals with hemophilia co infected with hepatitis $\mathrm{C}$ virus. Amongst HIV-1-negative individuals, women are known to have lower hemoglobin levels and a higher prevalence of anemia than men. As the shift in the HIV-1 epidemic has resulted in a large increase in the number of women infected, this may have implications for the incidence of anemia in those infected with HIV as well as for the use of hemoglobin and albumin as short- and long term prognostic markers of disease progression and death (S Shaw et al., 2007). Although increased ART coverage has led to substantial declines in mortality, mortality rates, especially during the first year after ART initiation, remain higher in African countries compared with higher income countries. Mortality rates of HIV-infected adults initiating ART in Africa have ranged from 8 to 16 deaths per 100 person-years.3-7 Established predictors of mortality in low-income settings include indicators of advanced HIV infection (i.e., low CD4 cell count and WHO clinical stage 4 disease), low hemoglobin, low body mass index (BMI), and certain opportunistic infections (e.g., tuberculosis). Several interventions have been proposed to reduce mortality in low-income settings, including promotion of earlier HIV diagnosis, treatment adherence support, and optimal prevention, screening, and management of opportunistic infections. Accurate identification of risk factors for mortality is a critical step toward reducing mortality in lowincome settings. Studies were conducted to identify risk factors of death within the first year after initiating ART among women with higher CD4 cell counts ( $>50$ cells/ $\mathrm{mm}^{3}$ ). Hypoalbuminemia has been previously shown to be a predictor of mortality among a cohort of HIV-infected women in the United States and among HIV-infected pa- 
tients initiating ART in London. The aetiology of hypoalbuminemia in HIV infection is often multifactorial and could indicate malnutrition, chronic inflammation due to advanced HIV infection, wasting syndrome, enteropathy, or liver disease (e.g., chronic hepatitis B virus co infection). Hypoalbuminemia was not predictive of mortality among women with low CD4 cell counts $\left(<50\right.$ cells $\left./ \mathrm{mm}^{3}\right)$ and this observation may have resulted from a plateau effect as women with a low CD4 cell count already have a high risk of mortality (20\%). Of interest, this interaction between albumin and CD4 cell count has also been observed among HIV-infected women in the United States. Electrolyte and protein abnormalities are rarely tested for in low-income settings because of limited laboratory capacity. In recent years, however, laboratory systems have improved substantially in several African countries and increasing numbers of HIV-infected patients have access to clinical chemistry testing. Adding testing for electrolytes and albumin and others in these settings would be relatively inexpensive, and evaluating the benefits of these tests prospectively is warranted (Christine N. Dao et al., 2011). A total of 131 patients were enrolled and evaluated by clinical assessment TLC and CD4 count. Clinical illnesses and TLC dichotomized at various cut-point values were used to determine the sensitivity, specificity, and positive and negative predictive values (PPV and NPV) forthediagnosisofCD4 count $<200$ cells/ $\mathrm{mm}^{3}$ among 100 participants fulfilling criteria for WHO clinical stage 2 and 3. A strong correlation was observed between TLC and CD4 $(r=0.73, p<0.0001)$. For all clinical syndromes, except pulmonary tuberculosis, the positive predictive values (PPV) for a CD4 count $<200$ cells/ $\mathrm{mm}^{3}$ were high $(>80 \%)$ but the negative predictive values (NPV) were low. Using the WHO recommended TLC cut-off of 1200 cells/mm3 to diagnose a CD4 less than 200cells/ $\mathrm{mm}^{3}$, the PPV was $100 \%$, and the NPV was $32 \%$. Our data showed a good correlation between TLC and CD4 cell count. However, the WHO recommended TLC cut-off of 1200 did not identify the majority of WHO stage 2 and 3 patients with CD4 counts less than 200 cells/ $\mathrm{mm}^{3}$. A more rational use of TLC counts is to treat all patients with WHO stage 2 and 3 who have a TLC $<1200$ cells $/ \mathrm{mm}^{3}$ and to limit CD4 counts to patients who are symptomatic but have TLC of $>1200 \mathrm{~mm}^{3}$ (Moses R. Kamyal et al., 2004). The inclusion of some important parameters of the ART toxicity-related assays such as platelet, haemoglobin, erythrocyte sedimentation rate (ESR), bilirubin (direct and indirect) and serum glutamate pyruvic transaminase (SGPT) could also be a cost saving strategy in the developing nations. Although the introduction of antiretroviral therapy to resource-limited countries should not be prevented because of a lack of monitoring tests, every effort should be made to introduce appropriate laboratory monitoring assays. Sustainability of assays (recognizing issues such as ongoing costs, delivery of reagents and kits, kit shelf-life, access to instrument service, and QA/QC programmes) must also be considered at the time of technology transfer. As a minimum, a low cost CD4+ T cell count should be monitored as an adjunct to clinical examination. Establishing CD4+ T cell monitoring facilities must include implementation of QA/QC program. Since there are some CD4+ count difference between standard assay and alternative technologies, the normal reference ranges should be established with the local population for any particular low-cost assay8. Implementation of low cost viral load assays awaits rigorous evaluation of their performance against standard assays. The incidence of HIV infection and clinical disease continue to increase rapidly in the developing nations14. As antiretroviral therapy is becoming more affordable and accessible in India, inexpensive laboratory tests are very much needed to monitor the disease progression and ART. Hence the implementation of HIV monitoring by low-cost assays would reduce the economic Burdon of the patients in this country (Pachamuthu Balakrishnan et al., 2005).

\section{Materials and Methods}

\subsection{Patient Group}

The study was carried out at the Department of Microbiology and immunoserology of Apollo Health City, Jubilee hills, Hyderabad between 2009 and 2012.In the present study we enrolled 542 individuals including 427 HIV seropositive patients who visited Integrated Counseling and Testing Centre (ICTC), Area Hospital, Siddipet and 125 normal healthy individuals who are HIV seronegative. The study was approved by institutional ethical committee. A proforma is filled consisting of clinical and other details of the patient and an informed and signed consent is obtained from the patients and controls. All the patients were antiretroviral therapy naive when the blood samples were first taken.

\subsubsection{Inclusion Criteria}

HIV seopositive patients who have been attending Integrated Councelling and testing Center (ICTC)

All HIV seropositives age above 15 years.

\subsubsection{Exclusion Criteria}

HIV seropositives on long term antiretroviral therapy

Who are seropositive for Hepatitis B virus and Hepatitis c virus

\subsection{Control Subjects}

The control group consisted of clinically normal subjects who are HIV seronegative recruited from the out patients of ICTC. Subjects were described about the study and an informed consent was obtained from them.

\subsection{Methods}

\subsubsection{Sample Collection}

Blood was collected and processed following our established laboratory protocol. $10 \mathrm{ml}$ blood was collected in to sterile vacoutainers containing heparin/EDTA anticoagulant and without anticoagulant for blood and serum samples 
respectively. The blood was centrifuged within 30 minutes at $3000 \mathrm{rpm}$ for 10 minutes. Plasma \& serum were separated. All the samples are preserved at -70 degrees until use. The study population is divided in to two sub groups based on the parameters tested. Sub group I include 370 HIV seropositive patients who are HAART naive and 100 Normal healthy individuals are included in the study as controls. The biological markers tested include CD4+ T cells, CD8+T cells, Haemoglobin (HB \%), Absolute Eosinophilic count (AEC), Total Leukocyte count (TLC),Erythrocyte Sedimentation ratio( ESR) and CReactive Protein (CRP). In the Sub group II we have included 57 HIV seropositive and antiretroviral therapy naive individuals and HIV seropositive patients presently on HAART since 3-6 months attending Integrated Counseling and Testing Centre (ICTC) situated at Area hospital Siddipet were enrolled in the study. A total of 25 Normal healthy individuals are included in the study as controls. The biological markers tested include The TCD4+ cell counts, Serum Albumin, Globulin, Serum Glutamate Oxaloacetae Transaminase (SGOT), Total protein, Total cholesterol, High density Lipoproteins (HDL), Low density Lipoprotein (LDL), Lactate Dehydrogenase (LDH) and Creatine Kinase (CK/MB). Absolute TCD4+cell counts, CD8+T-cell counts were measured using flow cytometry (MMWR Recommendations and Reports, 1992). TLC, HB\%, AEC and ESR were estimated using conventional haematological methods. CRP was evaluated by latex agglutination test (Immuno CRP-Latex Agglutination Test). Biochemical parameters were estimated using Diasys kits by an automated analyser.

\subsubsection{Procedure for TCD4+Cell Counts}

Their HIV status is confirmed by three different types of ELISA's commercially available kits, as recommended by the National AIDS Control Organization (NACO). Absolute TCD4+cell counts, CD8+T-cell counts were measured using flow cytometry (MMWR Recommendations and Reports, 1992). TLC, HB\%, AEC and ESR were estimated using conventional haematological methods. CRP was evaluated by latex agglutination test (Immuno CRP-Latex Agglutination Test). Biochemical parameters were estimated using Diasys kits by an automated analyser.

\subsubsection{Procedure for CD4T+Cell Counts}

Whole blood is incubated first with CD14 antibodylabeled latex spheres, followed by CD4 antibody-labeled latex spheres. RBC are lysed, the nuclei of the $\mathrm{WBC}$ are stained, and the intact cells, with latex spheres attached, are counted on a hemocytometer under a light microscope. $B$, Schematic representation of Dynabeads T4-T8 system (Dynal). Whole blood is first incubated with magnetic beads coated with CD14 antibody to label monocytes. A magnet is applied to capture the monocytes, and monocytedepleted blood is incubated with CD4 antibody-labeled magnetic beads. The magnet allows specific retention of these CD4+ T lymphocytes during washing steps, after which the cells are lysed and nuclei stained for counting on a hemocytometer under a microscope(light or fluorescence).

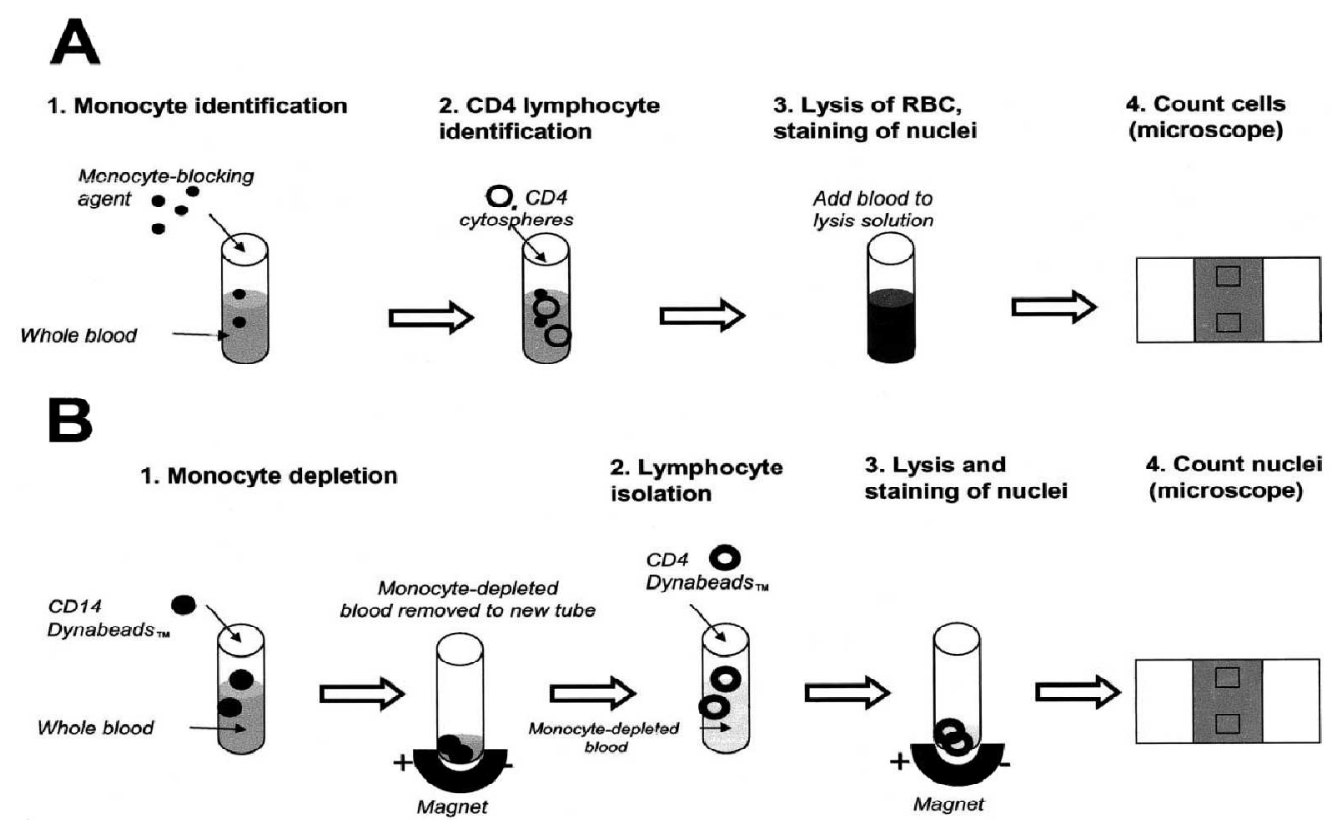

Figure 1. Diagram showing the procedure for CD4 T+ cell counts.

\subsubsection{ESR}

Westergren method:

The Westergren method requires collecting $2 \mathrm{ml}$ of venous blood into a tube containing $0.5 \mathrm{ml}$ of sodium citrate. It should be stored no longer than 2 hours at room tempera- ture or 6 hours at $4{ }^{\circ} \mathrm{C}$. The blood is drawn into a Westergren-Katz tube to the $200 \mathrm{~mm}$ mark. The tube is placed in a rack in a strictly vertical position for 1 hour at room temperature, at which time the distance from the lowest point of the surface meniscus to the upper limit of the red cell sediment is measured. The distance of fall of erythrocytes, 
expressed as millimeters in 1 hour, is the ESR.

Wintrobe method:

The Wintrobe method is performed similarly except that the Wintrobe tube is smaller in diameter than the Westergren tube and only $100 \mathrm{~mm}$ long. EDTA anti coagulated blood without extra diluent is drawn into the tube, and the rate of fall of red blood cells is measured in millimetres after 1 hour. The shorter column makes this method less sensitive than the Westergren method because the maximal possible abnormal value is lower. However, this method is more practical for demonstration purposes.

Red blood cells have settled, leaving plasma at the top of the tube. Reading: $18 \mathrm{~mm} /$ hour (Time: one hour)

Latex agglutination

Principle

Latex agglutination is observed when a sample containing the specific antigen (or antibody) is mixed with an antibody (or antigen) which is coated on the surface of latex particles.

Latex agglutination tests have been applied in clinical laboratories for the detection of infectious diseases and in 1956 Singer and Plotz first described Rheumatoid Factor Test, a test based on latex agglutination.

Since then, tests to detect microbial and viral infections, autoimmune diseases, hormones, drugs and serum proteins have been developed and marketed by many companies worldwide. The principle is used for the diagnosing many infections such as Hepatitis B, H.influenzae, N. meningitidis, etc. All methods of detecting or quantitating antigen or antibody take advantage of the fact that they react to form a complex. At the optimum antigen-antibody concentration, this complex precipitates out. However, if the antigen is particulate in nature, agglutination of antigen-antibody complex is observed.

Qualitative agglutination test

Agglutination tests can be used in a qualitative manner to assay for the presence of an antigen or an antibody. The antibody is mixed with the particulate antigen and a positive test is indicated by the agglutination of the particulate antigen.

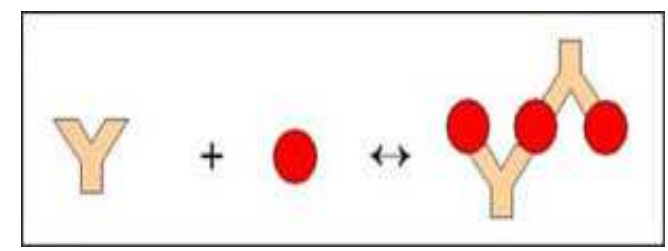

Figure 2. Diagramatic representation of Latex agglutination test.

For example, to determine patient's blood type the red blood cells of the person can be mixed with antibody to a blood group antigen. Another example is that to assay the presence of antibodies in a patient sample, the serum of the patient is mixed with the red blood cell (RBC) of a known blood type.

Quantitative agglutination test

To measure the level of antibodies to particulate antigens, agglutination test can be widely used. For this test, serial dilutions of the sample can be made and it is tested for antibody. Then a fixed amount of particulate antigen or bacteria or red blood cells can be added to it. Determine the maximum dilution which forms agglutination and this maximum dilution which gives observable agglutination is known as the titer. The result is shown as the reciprocal of the maximum dilution that forms visible agglutination.

The Latex Particles

Emulsion polymerization is the procedure that is applied for the preparation of latex particles. Firstly the styrene is mixed with the surfactant (sodium dodecyl sulfate) solution, forms a billions of emulsified micelles which are in uniform diameter. Then a little amount of potassium per sulfate is added to it which is a water soluble polymerization initiator. When the polymerization process is finished, the polystyrene chains are arranged into the micelles. The hydrocarbon part of the polystyrene chain is attached to the center and the terminal sulfate ion to the spheres surface which is exposed to the water phase. Other hydrocarbons and its derivatives are also used for the production of the uniform latex particles, some of the examples are stryrenedlvinylbenzene, polymethyl methacrylate, styrene vinyl toluene, polyvinyl toluene etc.

The process of latex particle production is evolved from synthetic rubber production and also the emulsion have a milky appearance, the term latex is given to it .The desired diameter of latex particle can be made by modifying the process of preparation, hydrocarbons, the surfactants and the initiator. The particle sizes of latexes are usually ranges between $0.05 \mu \mathrm{m}$ to $2 \mu \mathrm{m}$. Because of the presence of sulfate and sulfonate ions on the surface of the particle which provides a inherent negative surface charge to the particle.

The latex particles can be functionalized and surface treated to facilitate the binding stability and to increase analyte attachment. Functional treatments such as amidation, amination, carboxylation, hydroxylation and even magnetization are used to increase the properties of latex particles. Also various colors of latex particles are available commercially which facilitate the visual read -out.

The latex agglutination test is a clinical method to detect certain antigens or antibodies in a variety of bodily fluids such as blood, saliva, urine or cerebrospinal fluid. The sample to be tested is sent to the lab and where it mixed with latex beads coated with a specific antigen or antibody. The clumping of latex beads (agglutination) indicates the presence of suspected particles. Other hematological and biochemical parameters were measured using standard laboratory and clinical chemistry protocols (Teitz, 2008 and $\mathrm{P}$ Godkar, 2006)

\subsection{Statistical Methods}

Descriptive statistical analysis has been carried out in the present study. Results on continuous measurements are presented on Mean \pm SD (Min-Max) and results on categorical measurements are presented in Number (\%). Signi- 
ficance is assessed at $5 \%$ level of significance. The following assumptions on data is made, Assumptions: 1.Dependent variables should be normally distributed, 2.Samples drawn from the population should be random, Cases of the samples should be independent

Analysis of variance (ANOVA) has been used to find the significance of study parameters between three or more groups of patients, Student t test ( two tailed, independent) has been used to find the significance of study parameters on continuous scale between two groups Inter group analysis) on metric parameters. Leven1s test for homogeneity of variance has been performed to assess the homogeneity of variance. . Chi-square/ Fisher Exact test has been used to find the significance of study parameters on categorical scale between two or more groups. Statistical software: The Statistical software namely SAS 9.2, SPSS 15.0, Stata 10.1, MedCalc 9.0.1 ,Systat 12.0 and R environment ver.2.11.1 were used for the analysis of the data and Microsoft word and Excel have been used to generate graphs, tables etc. (Bernard Rosner., 2000 and Robert H Riffenburg., 2005)

\section{Result}

\subsection{General Characteristics and the Study Design}

The comparative study included a total of 427 subjects and controls $(\mathrm{N}=125)$. The study population is placed in to two groups based on the parameters tested. The age and gender wise distribution is shown in below tables

Table 1. Distribution of study population

\begin{tabular}{ll}
\hline Study Population & Number (n) \\
\hline Sub Group I & 370 \\
Sub Group II & 57 \\
Controls I & 100 \\
Controls II & 25 \\
Total & 552 \\
\hline
\end{tabular}

Table 2. Age distribution of patients studied (Sub Group 1)

\begin{tabular}{lllll}
\hline \multirow{2}{*}{ Age in years } & \multicolumn{3}{l}{ Cases } & \multicolumn{3}{l}{ Controls } \\
\cline { 2 - 5 } & No & $\%$ & No & \% \\
\hline$<20$ & 25 & 6.7 & 10 & 10 \\
$21-30$ & 114 & 30.8 & 25 & 25 \\
$31-40$ & 159 & 42.9 & 35 & 35 \\
$41-50$ & 37 & 10 & 10 & 10 \\
$51-60$ & 25 & 6.7 & 15 & 15 \\
$>60$ & 10 & 2.7 & 5 & 5 \\
Total & 370 & 100.0 & 100 & 100 \\
Mean \pm SD & $34.82 \pm 9.16$ & & $34.37 \pm 9.52$ \\
\hline
\end{tabular}

Table 3. gender distribution (Sub Group 1)

\begin{tabular}{lllll}
\hline & Cases & \multicolumn{3}{c}{ Controls } \\
\cline { 2 - 5 } Gender & No & $\%$ & No & $\%$ \\
\hline Male & 213 & 57.5 & 54 & 54 \\
Female & 157 & 42.4 & 46 & 46 \\
Total & 370 & 100.0 & 100 & 100 \\
\hline
\end{tabular}

Table 4. Age distribution of patients studied (Sub Group 2)

\begin{tabular}{lllll}
\hline & \multicolumn{3}{c}{ Cases } & \multicolumn{3}{c}{ Controls } \\
\cline { 2 - 5 } Age in years & No & $\%$ & No & $\%$ \\
& & & & 8.3 \\
\hline $17-20$ & 4 & 7.0 & 2 & 32.3 \\
$21-30$ & 17 & 29.8 & 8 & 32.3 \\
$31-40$ & 25 & 43.9 & 8 & 8.3 \\
$41-50$ & 3 & 5.3 & 3 & 12.5 \\
$51-60$ & 6 & 10.5 & 3 & 4.2 \\
$>60$ & 2 & 3.5 & 1 & 100.0 \\
Total & 57 & 100.0 & 25 & \\
Mean \pm SD & $36.33 \pm 11.67$ & & $35.92 \pm 12.98$ \\
\hline
\end{tabular}

Samples are age matched with $p=0.898$

Table 5. gender distribution (Sub Group 2)

\begin{tabular}{lllll}
\hline & Cases & \multicolumn{3}{c}{ Controls } \\
\cline { 2 - 5 } Gender & No & $\%$ & No & $\%$ \\
\hline Male & 31 & 54.4 & 17 & 68 \\
Female & 26 & 45.6 & 8 & 32 \\
Total & 57 & 100.0 & 25 & 100.0 \\
\hline
\end{tabular}

Samples are gender matched with $P=0.306$

\subsection{Sub Group I}

The mean Hemoglobin, AEC,TC,CD4+T-cells, CD8+Tcells, ESR and CRP in the HIV seropositive individuals were found to be $10.742 \mathrm{~g} \%, 391.8,8595,308$ and 976.208 cells $\mathrm{mm}-3,75.625 \mathrm{~mm}$ and $1.725 \mathrm{mg} \mathrm{dL}-1$ respectively. Our study results showed a significant positive correlation of CD8+T-cell counts, Hemoglobin, AEC and TLC against CD4+T-cell counts.ESR and CRP were found to be negatively correlating with CD4+T-cell counts. The Total Leucocyte counts positively correlated with CD4+Tcell counts. The study results showed a significant negative correlation of CD4+T-cell counts with ESR and CRP where as a positive correlation was observed against TLC, HB\% and AEC as shown in table 6 and 7 
Table 6. The mean, standard deviation of all the Parameters in HIV patients (Sub Group1)

\begin{tabular}{ll}
\hline Parameter & Mean \pm SD \\
\hline CD4+T-cell counts & $308.000 \pm 296.82$ \\
CD8+T-cell counts & $976.208 \pm 548.618$ \\
CD4: CD8 ratio & $0.314 \pm 0.198$ \\
TLC & $8595.800 \pm 2146.9$ \\
HB $(\%)$ & $10.742 \pm 2.464$ \\
AEC & $391.800 \pm 180.18$ \\
ESR & $75.625 \pm 29.03$ \\
CRP & $1.725 \pm 1.267$ \\
\hline
\end{tabular}

Table 7. Correlation of markers with CD4+T-cell counts CD4+T-cell counts (Sub Group 1)

\begin{tabular}{lll}
\hline Marker & $\begin{array}{l}\text { R (Correlation } \\
\text { coefficient) }\end{array}$ & P Value \\
\hline CD4+T-cell counts & & \\
TLC & 0.34 & $=0.0059^{*}$ \\
HB (\%) & 0.33 & $=0.0081^{*}$ \\
AEC & 0.32 & $=0.2270$ \\
ESR & -0.12 & $=0.0004^{*}$ \\
CRP & -0.41 & $<0.0001^{*}$ \\
\hline
\end{tabular}

The present study used a CD4 cell cutoff of $<200$ and $<$ 350 and compared the usefulness of alternate biomarkers. Among the tested alternative biological markers TLC $<1800$ cells $/ \mathrm{mm}^{3}$ was showing high specificity (100\%) in predicting CD4 counts $<200$ cells $/ \mathrm{mm}^{3}$, with an accuracy of $61.46 \%$. Hemoglobin and Absolute Eosinophilic count showed high specificity of $84.09 \%$ and $94.32 \%$ respectively in predicting CD4 counts below 350. ESR with $98.98 \%$ sensitivity and AEC having $83.67 \%$ sensitivity was able to predict CD4 counts $<200$ cells $/ \mathrm{mm}^{3}$. Absolute Eosinophilic count of more than 550 cells $/ \mathrm{mm}^{3}$ was showing 90.07 specificity and CRP $>1.2 \mathrm{mg} / \mathrm{dL}$ with 68.87 specificity in predicting CD4 counts $<200$. In agreement with other recent studies our studies also suggest TLC $<1800$ and $<2000$ cells $/ \mathrm{mm}^{3}$ may be more suitable for initiation of HAART. Moderate correlation was observed for Absolute Eosinophilic counts ( $\mathrm{r}-0.444$ and $\mathrm{p}<0.001)$ to predict CD4 counts $<500$ cells $/ \mathrm{mm}^{3}$. Hemoglobin ( $\mathrm{r} 0.377 \mathrm{p}<0.001$ ) was a useful alternate to predict CD4 counts $<200$ cells $/ \mathrm{mm}^{3}$. ESR ( $\mathrm{r}$ $-0.376 \mathrm{p}<0.001)$ and CRP $(\mathrm{r}-0.341 \mathrm{p}<0.001)$ were also correlating well with CD4 cell counts. As observed by other studies TLC of $<1200$ cells $/ \mathrm{mm}^{3}$ was ineffective in predicting T CD4+ cell counts. We tried value of TLC at two different cutoffs of $<1800$ and $<2500$ cells $/ \mathrm{mm}^{3}$. A recent study has tried to predict T CD4 cell counts $<200$ cells/ $\mathrm{mm}^{3}$ by using the WHO HIV/AIDS clinical staging and found it to be having low sensitivity. We have evaluated Hemoglobin (HB\%) and ESR in 120 HIV seropositive and on HAART for at least 3-6 months. The results showed that Hemoglobin (HB\%) was showing significant positive correlation $(\mathrm{r}=0.904, \mathrm{p}=0.22)$ with HAART as compared to $\mathrm{ESR}(\mathrm{r}=0.726, \mathrm{p}=0.00892)$ as shown in table 8 and 9

Table 8. Diagnostics performance of ESR, AEC, TLC, Hb and CRP for predicting the low CD4 count $(<200)$ (Sub Group1)

\begin{tabular}{|c|c|c|c|c|c|c|}
\hline & \multicolumn{3}{|c|}{ Sensitivity Specificity PPV } & \multirow{2}{*}{$\begin{array}{l}\text { NPV } \\
96.15\end{array}$} & \multirow{2}{*}{$\begin{array}{l}\text { Accuracy } \\
49.00\end{array}$} & \multirow{2}{*}{$\begin{array}{l}\text { P value } \\
<0.001 * \\
*\end{array}$} \\
\hline $\mathrm{ESR}>20$ & 98.98 & 15.56 & 43.56 & & & \\
\hline $\mathrm{AEC}>350$ & 83.67 & 58.94 & 56.94 & 84.76 & 68.67 & $\begin{array}{l}<0.001 * \\
*\end{array}$ \\
\hline $\mathrm{AEC}>550$ & 30.61 & 90.07 & 66.67 & 66.67 & 66.67 & $\begin{array}{l}<0.001 * \\
*\end{array}$ \\
\hline TLC $<250$ & 31.63 & 88.08 & 63.27 & 66.50 & 65.88 & $\begin{array}{l}<0.001 * \\
*\end{array}$ \\
\hline $\begin{array}{l}\text { TLC } \\
<1800\end{array}$ & 2.00 & 100.00 & 100.00 & 61.13 & 61.46 & $\begin{array}{l}<0.001^{*} \\
*\end{array}$ \\
\hline $\mathrm{Hb}<10$ & 37.76 & 77.48 & 52.11 & 65.73 & 61.85 & $0.009 * *$ \\
\hline $\mathrm{CRP}>1.2$ & 59.18 & 68.87 & 55.24 & 72.22 & 65.06 & $\begin{array}{l}<0.001^{*} \\
*\end{array}$ \\
\hline
\end{tabular}

Table 9. Diagnostics performance of ESR, AEC, TLC, Hb and CRP for predicting the low CD4 count (<350) (Sub Group3)

\begin{tabular}{|c|c|c|c|c|c|c|}
\hline & Sensitivity & Specificity & PPV & NPV & Accuracy & $P$ value \\
\hline $\mathrm{ESR}>20$ & 94.41 & 19.32 & 68.16 & 65.38 & 67.87 & $<0.001 * *$ \\
\hline $\mathrm{AEC}>350$ & 70.19 & 64.77 & 78.47 & 54.28 & 68.27 & $<0.001 * *$ \\
\hline $\mathrm{AEC}>550$ & 24.84 & 94.32 & 88.89 & 40.69 & 49.40 & $<0.001 * *$ \\
\hline TLC $<250$ & 26.09 & 92.05 & 85.71 & 40.50 & 49.40 & $<0.001 * *$ \\
\hline TLC $<1800$ & 1.24 & 100.00 & 100.00 & 35.63 & 36.14 & 0.541 \\
\hline $\mathrm{Hb}<10$ & 35.40 & 84.09 & 80.28 & 41.57 & 52.61 & $0.001 * *$ \\
\hline $\mathrm{CRP}>1.2$ & 47.20 & 67.05 & 72.38 & 40.97 & 54.22 & $0.032 *$ \\
\hline
\end{tabular}

\subsection{Sub Group II}

The results revealed a significant variation in all the parameters among the HIV seropositive patients who are antiretroviral therapy naïve when compared with normal healthy individuals. The TCD4+ cell counts and biochemical parameters showed a slight difference among the HIV seropositive patients who were HAART naïve and those on HAART as shown in. Serum albumin, Albumin: Globulin ratio, Total protein, $\mathrm{LDH}, \mathrm{CK} / \mathrm{MB}, \mathrm{HDL}$ and $\mathrm{LDL}$ : HDL ratio were found negatively correlating with TCD4+ cell counts in HIV seropositive patients who were antiretroviral therapy naïve. Only SGOT, CK/MB and HDL: LDL ratio negatively correlated in those who were on antiretroviral therapy as shown in. A pared t test of all the parameter showed statistically significant results with TCD4+ cell counts, Albumin: Globulin ratio, LDH, HDL, total Cholesterol, $\mathrm{CK} / \mathrm{MB}$, LDL and HDL: LDL ratio as shown in table 10 and 11. 
Table 10. Comparison of study variables in cases and controls (Sub Group2)

\begin{tabular}{llll}
\hline variables & Cases & Controls & P value \\
\hline HDL & $44.86 \pm 7.85$ & $43.46 \pm 9.57$ & 0.494 \\
LDL & $164.05 \pm 33.18$ & $87.42 \pm 14.33$ & $<0.001^{* *}$ \\
Total chol & $135.95 \pm 25.71$ & $104.54 \pm 19.23$ & $<0.001^{* *}$ \\
LDL/HDL ratio & $3.77 \pm 1.04$ & $2.12 \pm 0.63$ & $<0.001^{* *}$ \\
Chol/HDL ratio & $3.09 \pm 0.62$ & $2.56 \pm 0.92$ & $0.003^{* *}$ \\
LDH & $208.75 \pm 69.28$ & $160.13 \pm 47.11$ & $0.002^{* *}$ \\
CKMB & $17.12 \pm 8.76$ & $15.75 \pm 5.45$ & 0.480 \\
Total Protein & $7.63 \pm 1.05$ & $7.37 \pm 0.76$ & 0.272 \\
Albumin & $4.42 \pm 0.91$ & $4.43 \pm 0.50$ & 0.967 \\
Globumin & $3.27 \pm 1.26$ & $3.35 \pm 0.89$ & 0.767 \\
Alb/Glb ratio & $1.61 \pm 0.89$ & $1.55 \pm 0.49$ & 0.747 \\
SGOT & $37.84 \pm 31.73$ & $16.58 \pm 5.48$ & $0.002^{* *}$ \\
CD4 & $266.61 \pm 175.44$ & $1057.13 \pm 370.61$ & $<0.001^{* *}$ \\
GGT & $104.21 \pm 114.25$ & $29.21 \pm 7.75$ & $0.002^{* *}$ \\
SGPT & $21.64 \pm 10.64$ & $14.83 \pm 6.66$ & $0.005^{* *}$ \\
\hline
\end{tabular}

Student t test

Table 11. Comparison of study variables in cases and controls (Sub Group2)

\begin{tabular}{|c|c|c|c|c|}
\hline Variables & HAART -ve & HAART +ve & Controls & $P$ value \\
\hline HDL & $45.33 \pm 7.57$ & $44.05 \pm 8.43$ & $43.46 \pm 9.57$ & 0.680 \\
\hline LDL & $157.42 \pm 36.03$ & $175.43 \pm 24.42$ & $87.42 \pm 14.33$ & $<0.001 * *$ \\
\hline Total chol & $137.47 \pm 27.95$ & $133.33 \pm 21.71$ & $104.54 \pm 19.23$ & $<0.001 * *$ \\
\hline $\begin{array}{l}\text { LDL/HDL } \\
\text { ratio }\end{array}$ & $3.57 \pm 1.03$ & $4.12 \pm 0.99$ & $2.12 \pm 0.63$ & $<0.001^{* *}$ \\
\hline $\begin{array}{l}\text { Chol/HDL } \\
\text { ratio }\end{array}$ & $3.08 \pm 0.64$ & $3.10 \pm 0.59$ & $2.56 \pm 0.92$ & $0.014 *$ \\
\hline LDH & $220.42 \pm 79.04$ & $188.76 \pm 42.91$ & $160.13 \pm 47.11$ & $0.002 * *$ \\
\hline $\mathrm{CK} / \mathrm{MB}$ & $18.14 \pm 9.46$ & $15.38 \pm 7.31$ & $15.75 \pm 5.45$ & 0.351 \\
\hline Total Protein & $7.66 \pm 1.15$ & $7.58 \pm 0.88$ & $7.37 \pm 0.76$ & 0.523 \\
\hline Albumin & $4.44 \pm 1.04$ & $4.38 \pm 0.64$ & $4.43 \pm 0.50$ & 0.960 \\
\hline Globumin & $3.28 \pm 1.38$ & $3.25 \pm 1.05$ & $3.35 \pm 0.89$ & 0.954 \\
\hline $\mathrm{Alb} / \mathrm{Glb}$ ratio & $1.68 \pm 0.98$ & $1.51 \pm 0.72$ & $1.55 \pm 0.49$ & 0.714 \\
\hline SGOT & $\begin{array}{l}38.33 \\
\pm 35.32\end{array}$ & $37.00 \pm 25.20$ & $16.58 \pm 5.48$ & $0.007 * *$ \\
\hline CD4 & $\begin{array}{l}375.97 \\
\pm 124.81\end{array}$ & $79.14 \pm 22.06$ & $\begin{array}{l}1057.13 \\
\pm 370.61\end{array}$ & $<0.001 * *$ \\
\hline GGT & $\begin{array}{l}92.50 \\
\pm 105.92\end{array}$ & $\begin{array}{l}125.30 \\
\pm 128.02\end{array}$ & $29.21 \pm 7.75$ & $0.004 * *$ \\
\hline SGPT & $22.17 \pm 11.70$ & $20.63 \pm 8.47$ & $14.83 \pm 6.66$ & $0.017 *$ \\
\hline
\end{tabular}

ANOVA test

\section{Discussion}

HIV infection is associated with extended clinical latent period in which the infected patient/person remains symptom less. During this period the virus actively replicates resulting in clinical illness. It is important for physicians concerned in treating HIV infected patients to understand the factors affecting disease progression which can facilitate clinicians to monitor and take treatment decisions. In developing and poor countries which usually have ill equipped laboratories to perform CD4+T-cell counts and HIV RNA viral load; it becomes imperative for the clinicians to search for other available markers for disease progression and management. Our study results showed a significant positive correlation of CD8+T-cell counts, Hemoglobin, AEC and TLC against CD4+T-cell counts.ESR and CRP were found to be negatively correlating with CD4+Tcell counts. The CD4+T-cell counts, CD8+T-cell counts and CD4:CD8 ratio among the study group were found comparatively lower to those observed by Ray et al. (2006) and similar to other studies by (Sehgal et al., 2002 Chaudhary et al., 2008 and Walker et al., 2006). The Total Leukocyte counts positively correlated with CD4+Tcell counts as observed in other studies performed in India by Chaudhary et al., 2008). The study results showed a significant negative correlation of CD4+T-cell counts with ESR and CRP where as a positive correlation was observed against TLC, $\mathrm{HB} \%$ and AEC.

The study results show a clear picture of altered biochemical parameters in HIV seropositive patients as observed in previous report by (AC Ene et al., 2006) in Nigeria. The study results also confirms a recent research published by (S Rasheed et al., 2007) in USA showing the involvement of HIV infection alone and with no influence of HAART can deregulate the metabolic pathways. Serum albumin, Globulin, Albumin: Globulin ratio and Total protein were found to be statistically significant in HIV seropositive and HAART naïve patients as observed in previous studies. This observation agrees with previous study that suggested evaluation of these parameters in HIV seropositive patients before initiation of HAART therapy and regularly followed up to assess the treatment response (Langford, S.E et al., 2007). The serum SGOT, CK/MB, LDH, Total cholesterol, Total cholesterol :HDL ratio, LDL, LDL:HDL ratio were elevated after the HAART therapy as evidenced in previous studies indicating the possible development of Cardiovascular disease (CAD) due to antiretroviral therapy. The study results have clearly shown abnormal liver function tests in HIV patients who are not on HAART and revealed raised levels of serum GGTP, ALT and AST as compared to the normal healthy individuals. Results also have implicated the role of HAART in initiating liver damage even in the absence of other hepatotropic viruses as revealed by other studies (Jain MK et al., 2009 and Wyles DL et al ., 2005). Recent reports have indicated abnormal liver function tests in a multisystem disorder (Kalafateli $\mathrm{M}$ et al., 2012). Liver function has been influenced 
by various non-infectious factors such as smoking, diabetes, body mass index and hypertension (Khedmat $\mathrm{H}$ et al., 2007, Lee DH et al., 2003 and Guaraldi G et al ., 2008). What is very interesting here is that HIV, with its complex disease progression where the infected patients can survive even up to 20 years are at risk of developing multiple organ dysfunction. This can be attributed to various mechanisms of HIV pathogenesis including chronic inflammation, recurrent infections and drug related toxicities (Cooper L et al., 2007). Liver is one such organ which is most affected and if proper intervention is not done may cause severe morbidity and mortality.

The present study used a CD4 cell cutoff of $<200$ and $<$ 350 and compared the usefulness of alternate biomarkers. Among the tested alternative biological markers TLC $<1800$ cells $/ \mathrm{mm}^{3}$ was showing high specificity (100\%) in predicting CD4 counts $<200$ cells $/ \mathrm{mm}^{3}$, with an accuracy of $61.46 \%$. Hemoglobin and Absolute Eosinophilic count showed high specificity of $84.09 \%$ and $94.32 \%$ respectively in predicting CD4 counts below 350. ESR with $98.98 \%$ sensitivity and AEC having $83.67 \%$ sensitivity was able to predict CD4 counts $<200$ cells $/ \mathrm{mm}^{3}$. Absolute Eosinophilic count of more than 550 cells $/ \mathrm{mm}^{3}$ was showing 90.07 specificity and CRP $>1.2 \mathrm{mg} / \mathrm{dL}$ with 68.87 specificity in predicting CD4 counts $<200$. In agreement with other recent studies our studies also suggest TLC $<1800$ and $<2000$ cells $/ \mathrm{mm}^{3}$ may be more suitable for initiation of HAART. Moderate correlation was observed for Absolute Eosinophilic counts ( $\mathrm{r}-0.444$ and $\mathrm{p}<0.001)$ to predict CD4 counts $<500$ cells $/ \mathrm{mm}^{3}$. Hemoglobin ( $0.377 \mathrm{p}<0.001$ ) was a useful alternate to predict CD4 counts $<200$ cells $/ \mathrm{mm}^{3}$. ESR ( $\mathrm{r}$ $-0.376 \mathrm{p}<0.001)$ and CRP $(\mathrm{r}-0.341 \mathrm{p}<0.001)$ were also correlating well with CD4 cell counts. As observed by other studies TLC of $<1200$ cells $/ \mathrm{mm}^{3}$ was ineffective in predicting T CD4+ cell counts. We tried value of TLC at two different cutoffs of $<1800$ and $<2500$ cells $/ \mathrm{mm}^{3}$. A recent study has tried to predict T CD4 cell counts $<200$ cells $/ \mathrm{mm}^{3}$ by using the WHO HIV/AIDS clinical staging and found it to be having low sensitivity (Baveewo S et al., 2011 and WHO press., 2004). An Indian study evaluated hemoglobin, ESR and TLC and found TLC $<1200$ cells $/ \mathrm{mm}^{3}$ could predict CD $4<200$, with very low sensitivity (Sourav Sen et al., 2011). Another study recently used a prediction based classification(PBC) method using alternate biomarkers like total lymphocyte count in predicting CD4 cell counts thereby reducing the cost of patient management (Azzoni L et al., 2012). Few studies have used some biomarkers and found that pre HAART evaluation of such markers can predict Immune Reconstitution Inflammatory Syndrome (IRIS) (Boulware DR et al., 2010 and Martyn A H French., 2012). Another study in the developing country tried to evaluate non physician clinician's role in staging and monitoring HIV diastase (Paula E. Brentlinger et al., 2010). Absolute Eosinophilic count correlated well with CD4 cell counts in predicting the disease stage and thereby may prove to be a use full biomarker in assessing the disease progression as observed by (Alan J Cohen et al., 1996). Utility of ESR in the current study revealed that a raised ESR correlated well with CD4 cell counts (Accuracy 67.87\%) and could predict CD4 counts below 350 and can be used in decision on start of HAART and there by monitoring antiretroviral therapy (Ndakotsu MA et al., 2009). Few previous studies have found no correlation of CD4 cell counts less than 200 cells $/ \mathrm{mm}^{3}$ and ESR (Morpeth SC et al., 2007). Only scanty data on the usefulness of ESR in predicting CD4 cell counts is available in the literature review (Ndakotsu MA et al., 2009, David M LOWE., 2010 and Peters PJ et al., 2008). Current study results correlated well with a recent study which found anemia to be a use full predictor of CD4 cell counts below 200 cells $/ \mathrm{mm}^{3}$ (Owiredu WKBA et al., 2011). An Indonesian study showed good relation of anaemia with reduced CD4 cell counts as show by the current study which observed high specificity $(77.48 \%)$ and accuracy in predicting CD4 cell counts $<200$ cells $/ \mathrm{mm}^{3}$ (Wisaksana et al., 2011). Elevated CRP was a good predictor of CD $4<200$ as observed in the current study. Moderate correlation was observed in our study between anaemia and CD4 cells $<200$ cells $/ \mathrm{mm}^{3}$ as observed in a study (José A Mata-Marín et al., 2010). Another study from north India studied hematological profile in 470 HIV seropositive patients and found that moderate to severe anemia and leucopenia was associated with CD4 cell counts $<200$ cells $/ \mathrm{mm}^{3}$ (Suresh Venkata Satya Attili et al., 2008). Hematological abnormalities are a cause of concern in HIV infected individuals and could be use full in management of disease. Very few studies are available from India in this regard. Study also re emphasizes the need for rethink over TLC $<1200$ cells $/ \mathrm{mm}^{3}$ in predicting CD4 cell counts $<200$ cell $/ \mathrm{mm}^{3}$ and initiation of HAART (Baveewo S et al., 2011 and Sourav Sen et al., 2011). In another study from Uganda that evaluated low cost alternate blood markers in predicting CD4 $<200$ cell $/ \mathrm{mm}^{3}$ and found Anemia had sensitivity (95\% CI) of $47 \%$ and a specificity of 76\% (G Miiro et al., 2010). An Iranian study evaluated TLC counts $<1300$ cells $/ \mathrm{mm}^{3}$ (slightly higher than WHO recommended value) and found to be having optimum sensitivity and specificity in predicting CD4 $<200$ cell $/ \mathrm{mm}^{3}$ (Jafari S et al ., 2009). Study from Indonesia showed the utility of TLC among those on HAART and found that it was effective in predicting CD4 counts $<200$ cells $/ \mathrm{mm}^{3}$ (Marrigje A. de Jong et al., 2012). Another study revealed that TLC $<1700$ cells $/ \mathrm{mm}^{3}$ could predict $\mathrm{CD}<350$ cells $/ \mathrm{mm}^{3}$ (Helena P. W. et al., 2011). The current study results clearly indicate abnormal hematological parameters in HIV sero-positive patients. Among the tested biomarkers Absolute Eosinophilic counts of more than 550 cells $/ \mathrm{mm}^{3}$, Blood Hemoglobin less than $10 \mathrm{~g} \%$, ESR measuring more than $20 \mathrm{~mm}$, CRP value of $>1.2$ and TLC $<1800$ cells $/ \mathrm{mm}^{3}$ could be helpful in predicting CD4 cell counts $<350$ and $<200$ cells $/ \mathrm{mm}^{3}$.

\section{Conclusion}

The study has highlighted that there are some hemato- 
logical parameters that are abnormal in HIV seropositive patients when compared to normal healthy individuals. The present study results also indicate effectiveness of serum albumin, globulin, Albumin: Globulin ratio in predicting the disease stage or monitoring the disease progression in HIV infected and antiretroviral therapy naïve patients. The cardiovascular profile including the serum SGOT, CK/MB, LDH, Total cholesterol, Total cholesterol: HDL ratio, LDL, and LDL: HDL ratio can be beneficial in assessing the disease progression and treatment response in HIV infected patients who were on HAART therapy. The study results have also clearly shown abnormal liver function tests in HIV patients who are not on HAART and revealed raised levels of serum GGTP, ALT and AST as compared to the normal healthy individuals. Results also have implicated the role of HAART in initiating liver damage even in the absence of other hepatotropic viruses as revealed by other studies. The current study results clearly indicate abnormal hematological parameters in HIV sero-positive patients. Among the tested biomarkers Absolute Eosinophilic counts of more than 550 cells $/ \mathrm{mm}^{3}$, Blood Hemoglobin less than $10 \mathrm{~g} \%$, ESR measuring more than $20 \mathrm{~mm}$, CRP value of $>1.2$ and TLC $<1800$ cells $/ \mathrm{mm}^{3}$ could be helpful in predicting CD4 cell counts $<350$ and $<200$ cells $/ \mathrm{mm}^{3}$. The influence of these and other factors, on the clinical progression of HIV infection should be reviewed in detail, both preceding and following treatment initiation. The study results were found similar to previous studies and reaffirmed the importance of other available biological markers useful for monitoring the disease progression and disease management in HIV/AIDS patients. From the study results we consider lactate dehydrogenase (LDH), gammaGlutamy transpeptidase (GGT), Hemoglobin (HB) and Erythrocyte Sedimentation Rate (ESR) as potential putative markers of HIV disease progression and treatment response. These biological markers are also effective in predicting CD4 cell counts.

In conclusion we recommend that the Management of HIV/AIDS in the HAART era should include focusing on using our resources as effectively and efficiently as possible to maximize the benefit.

\section{Future Implication of the Study}

Over the time the profile of HIV epidemic has evolved from a life threatening to chronic disease, with the availability of better drugs (HAART) and thanks to some efficacious resource delivery modalities involving communities and people living with HIV infection. A revolutionary new approach in the treatment endorsed by UNAIDS and WHO, simplified HIV diagnostic technologies and gave hope for achieving universal access to prevention, care and treatment of HIV/AIDS even in resource constrained settings. HAART also has brought with it new challenges and issues for researchers involved in HIV/AIDS. This resulted in prolonging survival and quality of care for people living with HIV/AIDS. The knowledge of HIV infection has ex- panded tremendously that led to significant improvement in the treatment, leading to decrease in morbidity and mortality. Unfortunately the progress achieved in the development of treatment and vaccine has been restricted or confined to western world. Disease progression, initiation and assessment of antiretroviral therapy in HIV infected individuals depend on CD4+Tcell counts and HIV RNA viral load. However due to the limitations either in the scientific technology and infrastructure or with the finances, many developing and poor countries cannot afford the cost of these tests. Conversely HIV infection alone and the HAART may influence the disease course and therefore, research should concentrate on finding alternate and cost effective biological markers which can help physicians in deciding the start of antiretroviral therapy and predicting and managing HIV disease progression. The further course of the HIV-1 pandemic, therefore, mainly depends on how and to what degree developing countries with a high HIV-1 prevalence are able to take advantage of the medical progress achieved in Europe and North America, and whether an effective prophylactic vaccine will become available in the near future. An understanding of the immunopathogenesis of HIV1 infection is a major prerequisite for rationally improving therapeutic strategies. The influence of these and other factors, on the clinical progression of HIV infection should be reviewed in detail, both preceding and following treatment initiation.

The spectrum of HIV care needs to evolve in to a comprehensive primary care model that has an integrated, patient centred approach, and should be linked to specialist care where and when needed. Therefore, research should concentrate on finding alternate and cost effective biological markers which can help physicians in deciding the start of antiretroviral therapy and predicting HIV disease progression. HIV clinics should come up in the peripherals and the physicians treating the HIV patients should be involved in the management of such patients making use of the cheaper and alternate biological markers. Further studies should be encouraged to evaluate HIV-infected patients for various biological markers choose from them a set of markers that can effectively evaluate the disease state and probable time due for progression to AIDS and formulate effective intervention strategies in the management of HIV disease.

\section{List of Abstracts Submitted From This Thesis and Related Work}

Attended and presented Abstract "Role of Hematological markers and alternate markers in HIV disease progression" as a poster in the 2nd HIV Science Symposium held at the CSIR campus sponsored by CSIR, DBT, ICMR and YRG Care, Chennai 28-29 August 2009-POSTER

Attended and presented Abstract "Evaluation of Biochemical parameters and CD4+ T cell counts in HIV seropositive individuals attending Integrated Counseling and 
testing Center (ICTC)" as a poster in the 3nd HIV Science Symposium held at the CSIR campus sponsored by CSIR, DBT, ICMR and YRG Care, Chennai 30-31 August 2010POSTER

Attended and presented "A study of alternate biomarkers in HIV disease and evaluating their efficacy in predicting $\mathrm{T}$ CD4+ cell counts and disease progression in resource poor settings in Highly Active Antiretroviral Therapy (HAART) Era" at the National conference on Biomarkers in Health Diseases on 21st and 22nd February 2013 at National Institute of Miners Health (NIMH) sponsored by DBT, ICMR and DST

\section{Scholarships/ Awards}

Received Scholarship at the $2^{\text {nd }}$ Annual HIV Science Symposium held at YRG Care center, CSIR Campus, Chennai, sponsored by CSIR, DBT, ICMR and YRG Care, Chennai 28-29 August 200.

\section{References}

[1] Andrea Sebben Kramer, Alexandre Ramos Lazzarotto, Eduarado Sprinz, Waldomiro Carlos Manfroi. Metabolic abnormalities, Antiretroviral therapy and cardiovascular disease in elderly patients with HIV. Arq Bras Cardiol 2009; 93(5): 519-526.

[2] A.C., Ene, T.O. Harry, A.A. Gadzama, B.B. Ajayi, B.M. Bintube and D.N. Bukbuk. Biochemical abnormalities associated with HIV-1 infection as observed in Maiduguri, North-eastern Nigeria. Research Journal of Medicine and Medical sciences, 2006; 1(2): 82-84.

[3] Alan J. Cohen and Roy T. Steigbigel. Eosinophilia in Patients Infected with Human Immunodeficiency Virus. JID 1996; 174: 615-8

[4] Azzoni L, Foulkes AS, Liu Y, Li X, Johnson M, et al. Prioritizing CD4 Count Monitoring in Response to ART in Resource-Constrained Settings: A Retrospective Application of Prediction-Based Classification. PLoS Med 2012; 9(4): e1001207. doi:10.1371/journal.pmed.1001207

[5] Barbaro G. Visceral fat as target of highly active antiretroviral therapy-associated metabolic syndrome . Curr. Pharm. Des 2007; 13: 2208-2213.

[6] Boulware DR, Meya DB, Bergemann TL, Wiesner DL, Rhein J, et al. Clinical Features and Serum Biomarkers in HIV Immune Reconstitution Inflammatory Syndrome after Cryptococcal Meningitis: A Prospective Cohort Study. PLoS Med 2010; 7(12): e1000384. doi:10.1371/journal.pmed.1000384

[7] Baveewo S, Ssali F, Karamagi C, Kalyango JN, Hahn JA, et al. Validation of World Health Organisation HIV/AIDS Clinical Staging in Predicting Initiation of Antiretroviral Therapy and Clinical Predictors of Low CD4 Cell Count in Uganda. PLoS ONE 2011; 6(5): e19089. doi:10.1371/journal.pone.0019089

[8] Bernard Rosner (2000), Fundamentals of Biostatistics, $5^{\text {th }}$ Edition, Duxbury, page 80-240
[9] Berhane, K., R. Karim, M.H. Cohen, L. Masri-Lavine and M. Young et al.,. Impact of highly active antiretroviral therapy on anemia and relationship between anemia and survival in a large cohort of HIV-infected women: Women's interagency HIV study J. Acquir. Immune Defic. Syndr., 2004; 37: $1245-1252$.

[10] Carr, A., K. Samaras, S. Burton, M. Law and J. Freund et $a l .,$. A syndrome of peripheral lipodystrophy, hyperlipidaemia and insulin resistance in patients receiving HIV protease inhibitors. AIDS, 1998; 12: F51-F58.

[11] Chaudhary, M., B. Kashyap, H. Gautam, S. Saini and P. Bhalla,. Use of surrogate markers to predict the HIV disease stage and time to initiate antiretroviral therapy in developing countries. J. Int. Assoc, Phys. AIDS Care, 2008; 7: 259-264. DOI: $10.1177 / 1545109708322302$

[12] Clamy A, Gayet-Ageron A, Montecucco F, Nguyen A, Mach $\mathrm{F}$, et al. HIV increases markers of cardiovascular risk, results from a randomized treatment interruption trial. AIDS2009; 23: 929-939

[13] Cooper CL. HIV antiretroviral medications and hepatotoxicity. Curr Opin HIV AIDS 2007 ; 2: 466-473.

[14] Choi S, Lagakos SW, Schooley RT, Vollberding PA CD4+ lymphocytes are an incomplete surrogate marker for clinical progression in persons with asymptomatic HIV infection taking Zidovudine. Ann Intern Med 118: 674-680

[15] Christine N. Dao, Philip J. Peters, James N. Kiarie, Isaac Zulu, Peter Muiruri, John Ong'ech, Winfred Mutsotso, Dara Potter, Lungowe Njobvu, Jeffrey S.A. Stringer, Craig B. Borkowf. Omotayo Bolu, and Paul J. Weidle. Hyponatremia, Hypochloremia, and Hypoalbuminemia Predict an Increased Risk of Mortality During the First Year of Antiretroviral Therapy Among HIV-Infected Zambian and Kenyan Women. AIDS Res Hum Retroviruses 2011; 27(14). DOI: 10.1089/aid.2010.0345

[16] David M LOWE. The ESR in HIV: A Neglected Parameter? AIDS. 2010; 24(18): 2773-2775. doi:10.1097/QAD.0b013e32833ef5d7.

[17] Friis-Moller N, Reiss P, Sabin CA, Weber R, Monforte AA, El-Sadr W, et al. Class of antiretroviral drugs and the risk of myocardial infarction. N Engl Med. 2007; 356:1723-35.

[18] Guaraldi G, Squillace N, Stentarelli C, Orlando G, D'Amico R Nonalcoholic fatty liver disease in HIV infected-patients referred to a metabolic clinic: prevalence, characteristics, and predictors. Clin Infect Dis 2008; 47: 250-257.

[19] G. Miiro, S. Nakubulwa, C. Watera, P. Munderi, S. Floyd, H Grosskurth. Evaluation of affordable screening markers to detect CD4+ T-cell counts below 200 cells/ $\mu$ l among HIV-1infected Ugandan adults. Tropical Medicine \& International Health 2010; 15(4):396-404. DOI: 10.1111/j.13653156.2010.02471.x

[20] HO Olawumi and PO Olatunji. The value of Serum Albumin in pretreatment assessment and monitoring of therapy in HIV/AIDS patients. HIV Medicine 2006; 7: 351-355.

[21] Helena P. W. Oudenhoven, Hinta Meijerink, Rudi Wisaksana, Suryani Oetojo, Agnes Indrati, Andre J. A. M. van der Ven, Henri A. G. H. van Asten, Bachti Alisjahbana, Reinout van Crevel. Total lymphocyte count is a good marker for HIV-related mortality and can be used as a tool for starting 
HIV treatment in a resource-limited setting. Tropical Medicine \& International Health 2011; 16(11):1372-79 DOI: 10.1111/j.1365-3156.2011.02870.x

[22] Jeffrey J. Sevigny, Steven M. Albert, Michael P. McDermott, Giovanni Schifitto, Justin C. McArthur, Ned Sacktor, Katherine Conant, Ola A. Selnes, Yaakov Stern, Daniel R. McClernon, Donna Palumbo, Karl Kieburtz, Garrett Riggs, Bruce Cohen, Karen Marder, and Leon G. Epstein.An Evaluation of Neurocognitive Status and Markers of Immune Activation as Predictors of Time to Death in Advanced HIV Infection Arch Neurol, 2007; 64: 97 - 102.

[23] Jain MK. Mortality in Patients Coinfected with Hepatitis B Virus and HIV: Could Antiretroviral Therapy Make a Difference? Clin Infect Dis 2009; 48: 1772-1774

[24] Jafari S, Rasoolinejad M, Emadi Kouchak H Mokarami F. The relationship between total lymphocyte count and CD4 count in patients infected with HIV. Tehran Medical Journal 2009; 67(7): 477-482

[25] Khedmat H, Fallahian F, Abolghasemi H, Hajibeigi B, Attarchi Z. Serum gamma- glutamyltransferase, alanine aminotransferase, and aspartate aminotransferase activity in Iranian healthy blood donor men. World J Gastroenterol 2007; 13: 889-894.

[26] Kamat, A., V. Ravi, A. Derai, P. Satish Chandra, K.S. Satish and M. Kumar,. Estimation of virological and immunological parameters in subjects from south India infected with human immunodefeciency virus type- 1 clade $\mathrm{C}$ and correlation of findings with occurrence of neurological disease. J. Neurovirol., 2008; 15: 25-35.

[27] Kannangai, R., A.J. Kandathil, D.L. Ebenzer, E. Mathai and A.J. Prakash et al.,. Usefulness of Alternate prognostic serum and plasma markers for antiretroviral therapy for $\mathrm{Hu}-$ man immunodefeciency virus type-1 infection. Clin. Vaccine Immunol., 2008; 15: 154-158.

[28] Kramer AS, Lazzarotto AR, Sprinz E, Manfroi WC. Metabolic abnormalities, Antiretroviral therapy and cardiovascular disease in elderly patients with HIV. Arq Bras Cardiol 2009; 93: 561-568.

[29] Kalafateli M, Triantos C, Tsamandas A, Kounadis G, Labropoulou-Karatza C . Abnormal liver function tests in a patient with myotonic dystrophy type 1 Annals of Hepatology 2012; 11: 130-133

[30] Leghmari K, Bennasser Y, Tkaczuk J, Bahraoui E . HIV-1 Tat protein induces IL-10 production by an alternate TNFalpha-independent pathway in monocytes; role of PKC-delta and p38 MAP kinase. Cell immunol 2008; 253: 45-53

[31] Lehmann MH, Walter S, Ylisastigui L, Striebel F, Ovod V, et al. Extracellular HIV-1 Nef increases migration of monocytes. Exp Cell res 2006; 132:3659-3668.

[32] Langford, S.E., J. Anaaworanich and D.A. Cooper. Predictors of disease progression in HIV infection: A review. AIDS Res. Ther., 2007; 4: 11.

[33] Lee DH, Ha MH, Kim JH, Christiani DC, Gross MD, et al. Gamma-glutamyltransferase and diabetes--a 4 year follow-up study. Diabetologia 2003; 46: 359-364.

[34] Miedema, F.,. T-cell dynamics and protective immunity in HIV infection: A brief history of disease. Curr. Opin. HIV AIDS, 2006; 1: 1-2.
[35] MMWR Recommendations and Reports, 1992. Guidelines for performance of $\mathrm{CD} 4+\mathrm{T}$-cell determinations in persons with Human Immunodeficiency virus infection. http://www.cdc.gov/mmwr/preview/mmwrhtml/00019952.ht $\mathrm{m}$

[36] Mata-Marín et al.: Risk factors and correlates for anemia in HIV treatment-naïve infected patients: a cross-sectional analytical study. BMC Research Notes 2010; 3:230.

[37] Marrigje A. de Jong, Rudi Wisaksana, Hinta Meijerink, Agnes Indrati, Andre J. A. M. van de Ven, Bachti Alisjahbana, Reinout van Crevel. Total lymphocyte count is a reliable surrogate marker for CD4 cell counts after the first year of antiretroviral therapy: data from an Indonesian cohort study. Tropical Medicine \& International Health 2012; 17(5):581583 DOI: $10.1111 / \mathrm{j} .1365-3156.2012 .02961 . x$

[38] Morpeth SC, Crump JA, Shao HJ, Ramadhani HO, Kisenge PR, Moylan CA, et al. Predicting CD4 lymphocyte count $<200$ cells/mm(3) in an HIV type 1-infected African population. AIDS Res Hum Retroviruses 2007; 23(10):1230-6. [PubMed: 17961109]

[39] Martyn A H French. Immune reconstitution inflammatory syndrome: immune restoration disease 20 years on. MJA 2012; 196:318-321 doi: 10.5694/mja12.10089

[40] Moses R. Kamya, Fred C. Semitala, Thomas C Quinn, Allan Ronald, Denise Njama-Meya, Harriet Mayanja-Kizza1, Elly T. Katabira and Lisa A. Spacek. Total lymphocyte count of 1200 is not a sensitive predictor of CD4 lymphocyte count among patients with HIV disease in Kampala, Uganda. African Health Sciences 2004; 4(2): 94-101

[41] National AIDS Control Organisation (NACO) (2008). UNGASS country progress report 2008: India. New Delhi, Ministryof Health and Family Welfare.

[42] National AIDS Control Organization (NACO), 2006. HIV/AIDS Epidemiological surveillance and estimation report for the year 2005. National AIDS Control Organization, New http://www.aidsportal.org/repos/Fnlapil06rpt.pdf

Delhi.

[43] Ndakotsu MA, Salawu L, Durosinmi MA. Relation between erythrocyte sedimentation rate, clinical and immune status in HIV-infected patients. Niger J Med 2009; 18(2):208-10. [PubMed: 19630332]

[44] O.A. Ajose, S.O. Banjoko, O.A. Olasode, V.A. Oyegunle and J.B. Fakunle. Plasma biochemical parameters as prognostic markers in HIV-1 infected patients. Research Jopurnal of Medical Sciences, 2008; 2(4): 163-165.

[45] Owiredu WKBA, Quaye L, Amidu N, Addai-Mensah O. Prevalence of anaemia and immunological markers among Ghanaian HAART-naïve HIV-patients and those on HAART. African Health Sciences 2011; 11(1): 2 - 15

[46] Pere Domingo, Ignacio Suarez-Lozano, Ramon Teira, Fernando Lozano, Alberto Torron, Pompeyo Viciana, Juan Gonzalez, M Jose Galindo, Paloma Geijo, Antonio Vergara, Jamie Cosin, Esteban Ribera, Bernardino Roca, M Lucia Gracia-Alcalde, Trinitaro Sanchez, Ferran Torres, Juan Ramon Lacalle and Myriam Garrido. Dyslipidemia and cardiovascular disease risk factor management in HIV-1 infected subjects treated with HAART in Spanish VACH cohort. The Open AIDS Journal, 2008; 2:26-38.

[47] Paula E. Brentlinger, Jose' Vallejo Torres, Pilar Mart'inez 
Mart'inez, Annette Ghee, Johnny Lujan, Rui Bastos, Rolanda Manuel, Florindo M. Mudender, and Ame'rico Assan. Clinical Staging of HIV-Related Illness in Mozambique: Performance of Non physician Clinicians Based on Direct Observation of Clinical Care and Implications for Health Worker Training. J Acquir Immune Defic Syndr 2010; $55: 351-355$

[48] Peters PJ, Zulu I, Kancheya NG, Lakhi S, Chomba E, Vwalika C, et al. Rwanda Zambia HIV Research Group. Modified Kigali combined staging predicts risk of mortality in HIV-infected adults in Lusaka, Zambia. AIDS Res Hum Retroviruses 2008; 24(7):919-24. [PubMed: 18593343]

[49] Papadopulos-Eleopulos E . Reppraisal of AIDs Is the oxidation induced by risk factors the primary cause? Med Hypotheses 1988; 25: 151-162

[50] Pachamuthu Balakrishnan, Suniti Solomon, Nagalingeswaran Kumarasamy \& Kenneth H. Mayer. Low-cost monitoring of HIV infected individuals on highly active antiretroviral therapy (HAART) in developing countries. Indian $\mathrm{J}$ Med Res, April 2005; 121: 345-355

[51] Praful B Godkar, Darshan P Godkar. Textbook of Medical Laboratory Technology. 2nd edition. Bhalani Publishing House, 2006 - 1094 p ISBN8185578583, 9788185578583

[52] Ramana, K.V. and S.K. Mohanty,. Opportunistic intestinal parasites and TCD4+cell counts In Human immunodeficiency virus seropositive patients. J. Med. Microbiol., 2009; 58: $1664-1666$

[53] Rasheed S, Yan JS, Lau A, Chan AS. HIV replication enhances production of free fatty acids, low density lipoproteins and many key proteins involved lipid metabolism: Aproteomics study. PLoS ONE 2008; 3(8):e303.doi:10.13/1/journal.pone.0003003.

[54] Robert H Riffenburg. Statistics in Medicine, second edition, Academic press. 2005, 85-125.

[55] Ray, K., S.M. Gupta, M. Bala, S. Muralidhar and J. Kumar,. CD4/CD8 lymphocyte counts in healthy, HIV positive individuals and AIDS patients. Indian J. Med. Res., 2006; 124: 319-330. PMID: 17085836

[56] Sevigny, J.J., S.M. Albert, M.P. McDermott, G. Schifitto and J.C. McArthur et al.,. An evaluation of neurocognitive status and markers of immune activation as predictors of time to death in advanced HIV infection. Arch. Neurol., 2007; 64: 97-102. http://www.ncbi.nlm.nih.gov/pubmed/17210815

[57] Sunder Rao P S S, Richard J : An Introduction to Biostatistics, A manual for students in health sciences, New Delhi: Prentice hall of India. 86-160

[58] S. H. Kapiga, D. Mwakagile, D. Spiegelman, G. I. Msamanga, D. Hunter and W. W. Fawzi. Predictors of CD4+ Lymphocyte count among HIV-Seropositive and HIVSeronegative pregnant women in Dares Salaam, Tanzania. East African Medical Journal 2000; 77 (4)
[59] Spacek, L.A., M. Jriswold, T.C. Quinn and R.D. Moore,. Total lymphocyte count and hemoglobin combined in an algorithm to initiate the use of highly active antiretroviral therapy in resourcelimited settings. AIDS, 2003; 17: 13111317.

[60] Sehgal, S., V. Datta, S. Mujtaba, A. Sood and V.K. Vinaya$\mathrm{ka}$.. Cellular and serological markers of disease activity in Indian patients with HIV/AIDS. Methods Cell. Sci., 2002; 24: $107-114$.

[61] Sourav Sen., Akshat Vyas, Sunil Sanghi, K Shanmuganandan, RM Gupta, Ketoki Kapila, AK Praharaf, Satish Kumar, RB Batra. Correlation of CD4+ T cell Count with Total Lymphocyte Count, Haemoglobin and Erythrocyte Sedimentation Rate Levels in Human Immunodeficiency Virus Type-1 Disease. MJAFI 2011; 67: 15-20

[62] Suresh Venkata Satya Attili, V. P. Singh, Madhukar Rai, Datla Vivekananda Varma, K. Gulati, Shyam Sundar. Hematological profile of HIV patients in relation to immune status - a hospital-based cohort from Varanasi, North India. Turk J Hematol 2008; 25:13-19

[63] S Shah, CJ Smith, F Lampe, M Youle, MA Johnson, AN Phillips and CA Sabin. Haemoglobin and albumin as markers of HIV disease progression in the highly active antiretrovial therapy era: relationships with gender. HIV Medicine $2007 ; 8,38-45$

[64] Tietz Fundamentals of Clinical Chemistry, 6th edition. Carl A. Burtis, Edward R. Ashwood, and David E. Bruns, editors. St Louis, MO: Saunders/Elsevier, 2008, 976 pp, ISBN 9780-7216-3865-2.

[65] WHO: Scaling up antiretroviral therapy in resource-limited settings: treatment guidelines for a public health approach 2003 revision (Monograph online). Switzerland: WHO press; 2004. . Available from: http://www.who.inU hiv/pub/prev 3areieniarvrevision2003en.pdf.

[66] Wisaksana et al.: Anemia and iron homeostasis in a cohort of HIV-infected patients in Indonesia. BMC Infectious Diseases $2011 ; 11: 213$.

[67] UNAIDS., 2006. AIDS epidemic update. Joint United Nations Programme on HIV/AIDS (UNAIDS), Geneva. http://2006_Epiupdate_en.pdf

[68] Walker, A.S., V. Mulenga, F. Sinyinza, K. Lishimpi and A. Nunn et al.,. Determinants of survival without antiretroviral therapy after infancy in HIV- 1-infected Zambian children in the CHAP trial. J. Acquir. Immune Defic. Syndr., 2006; 42: 637-645. PMID: 16868501

[69] Wyles DL, Gerber JG Antiretroviral drug pharmacokinetics in hepatitis with hepatic dysfunction. Clin Infect dis 2005; 40: $174-181$

[70] World Health Organization, United Nations Children's Fund, UNAIDS (2009). Towards universal access: scaling uppriority HIV/AIDS interventions in the health sector. Progress report 2009. Geneva, World Health Organization. 